\title{
Renal Sympathetic Denervation in Resistant Arterial Hypertension: Long Term and Updated Results
}

\section{J. H. PEREGRIN ${ }^{1}$, J. NOVOTNÝ ${ }^{1}$, T. ROHÁL ${ }^{2}$, J. ŠOCHMAN ${ }^{3}$}

${ }^{1}$ Department of Diagnostic and Interventional Radiology, Institute for Clinical and Experimental Medicine, Prague, Czech Republic, ${ }^{2}$ Clinic of Nephrology, Institute for Clinical and Experimental Medicine, Prague, Czech Republic, ${ }^{3}$ Clinic of Cardiology, Institute for Clinical and Experimental Medicine, Prague, Czech Republic

Received August 23, 2018

Accepted November 13, 2018

\section{Summary}

The present paper is an extension to our earlier publication (Šochman et al. 2016) documenting a beneficial effect of renal sympathetic denervation on pharmacologically uncontrollable hypertension in a group of seven patients followed up for 1-2 years post-procedure. The same patients remained on ambulatory follow-up for another 5-6 years, with the beneficial effect persisting throughout the follow-up period while on the same medication.

\section{Key words}

Hypertension • Renal sympathetic denervation • Uncontrollable blood pressure

\section{Corresponding author}

J. H. Peregrin, Department of Diagnostic and Interventional Radiology, Institute for Clinical and Experimental Medicine, Vídeňská 1958/9, 14021 Prague 4, Czech Republic. E-mail: Jan.Peregrin@seznam.cz

Renal sympathetic denervation (RSD) as a therapeutic option in conservatively uncontrollable hypertension has experienced a dramatic twist in recent years. While, after the initial results of the SYMPLICITY HTN-1 and -2 trials became available, RSD was looked up to as a revolutionary therapeutic modality, but the procedure was virtually discarded after the publication of the SYMPLICITY HTN-3 trial results. Still, the fact that a small proportion of patients did respond to RSD by a reduction of high blood pressure $(\mathrm{BP})$ has never been challenged; however, there is no clue to identify RSD responders before the procedure.

The present paper is an extension to our earlier publication (Šochman et al. 2016) presenting the outcome of seven patients undergoing RSD, which resulted in long-term BP reduction while on unchanged or decreased medication. The patients were on follow-up for at least 22 months. In this paper, the authors report data obtained during further clinical follow-up of these patients over a period of 24-72 months post-RSD.

Our follow-up group of seven patients included 5 men and 2 women, with a mean age of 64.9 years at the time of RSD. All had ambulatory BP monitoring by the same team as in previous years using the same technique as in the first two years. Table 1 presents more detailed patient characteristics. All other details can be found in our original article (Šochman et al. 2016).

Follow-up changes in systolic blood pressure and antihypertensive medication (number of drugs) are shown in Figures 1-2. As clearly seen in the graphs with new data starting one to two years post-RSD, BP levels remained decreased over the next two to four years in all seven patients receiving the same or only slightly changed antihypertensive medication. Importantly, no RSD-related complications were observed throughout the follow-up period.

Catheter-based RSD as a procedure employed for the treatment of pharmacologically uncontrollable hypertension has experienced a dramatic twist in recent years. After the publication of the SYMPLICITY HTN-1 
and -2 results, the procedure enjoyed up to uncritical popularity performed as it was in large patient populations worldwide (Esler et al. 2010, Krum et al. 2009). However, when data of the SYMPLICITY HTN-3 project as a randomized sham-controlled trial became available in 2014 (Bhatt et al. 2014), not confirming a statistically significant beneficial effect on $\mathrm{BP}$ reduction, RSD fell into disfavor within a short period of time.

Table 1. Characteristics of 7 patients with resistant hypertension undergoing RSD.

\begin{tabular}{|c|c|c|}
\hline & & Note \\
\hline Gender $\widehat{\partial} / Q$ & $5 / 2$ & \\
\hline Mean age (range 61-68 years) & 64.9 & \\
\hline Average BMI $\left(\mathrm{kg} / \mathrm{m}^{2}\right)$ & $32.3 \pm 4.5$ & \\
\hline \multicolumn{3}{|l|}{ Medication: } \\
\hline Beta-blocker & $7 / 7$ & \\
\hline Angiotensin receptor blocker & $7 / 7$ & \\
\hline Calcium-channel blocker & $6 / 7$ & \\
\hline Alpha 1 adrenergic receptor blocker & $5 / 7$ & \\
\hline$\alpha$ blocker + central 5-HXT receptor agonist & $4 / 7$ & \\
\hline Diuretic & $7 / 7$ & \\
\hline Mean creatinine $(\mu \mathrm{mol} / \mathrm{l})$ & $86.7 \pm 15.9$ & \\
\hline Mean cholesterol (mmol/l) & $5.25 \pm 0.7$ & \\
\hline Mean glycemia (mmol/l) & $5.65 \pm 0.45$ & \\
\hline Mean COP (pmol/l) & $7.26 \pm 3.55$ & No change in levels at follow-up visits \\
\hline Mean proADM (nmol/l) & $0.67 \pm 0.15$ & No change in levels at follow-up visits \\
\hline Mean proANP (pmol/l) & $118.59 \pm 55.14$ & No change in levels at follow-up visits \\
\hline
\end{tabular}

BMI - body mass index; 5-HXT - 5-hydroxytryptamine; COP - copeptin; proADM - proadrenomedullin; proANP - pronatriuretic peptide.

After some time, RSD was re-assessed in seven trials (two of which were sham-controlled ones) (Fadl Elmula et al. 2015). Results of these studies copying the SYMPLICITY trial design failed to demonstrate significant improvement in BP control compared with medical therapy. Still, significant improvement in BP control (i.e. an antihypertensive effect) has not been completely challenged in a small proportion of RSD patients; however, this subpopulation has not been clearly defined yet. Several recent studies have shown that RSD is successful in hypertension control in at least some patients; these studies include the French DENERHTN trial published in 2015 (Azizi et al. 2015) reporting a reduction in high BP levels post-RSD. A repeat analysis of SYMPLICITY HTN-3 data revealed that, in patients with isolated systolic hypertension, the effect of RSD is smaller to zero compared with individuals with systolicdiastolic hypertension (Mahfoud et al. 2016). At the same time, two studies, SPYRAL HTN-OFF MED (Townsend et al. 2017) and SPYRAL HTN-ON MED (Kandzaride et al. 2018), showed BP reduction post-RSD including comparison with a sham-procedure. However, these two studies also used catheters (multi-electrode) other than the original (uni-electrode) Symplicity device.

All in all, RSD seems to be effective - at least in a proportion of hypertensive patients - in decreasing elevated BP levels; unfortunately, researchers have to date been unable to identify those responsive to the procedure.

The question is, whether RSD using the original Symplicity uni-electrode catheter was as complete as anticipated. In an animal study, the uni-electrode catheter was shown to be inferior to the multi-electrode one in destroying sympathetic nerves, although the latter may also fail to achieve complete denervation (Táborský et al. 2017, Táborský et al. 2018). Other animal studies using chemical agents to accomplish RSD did show a reduction of high BP levels (Consigny et al. 2014); however, respective human studies are lacking except for a pilot one with RSD using CT-guided ethanol injection (Ricke et al. 2016). 


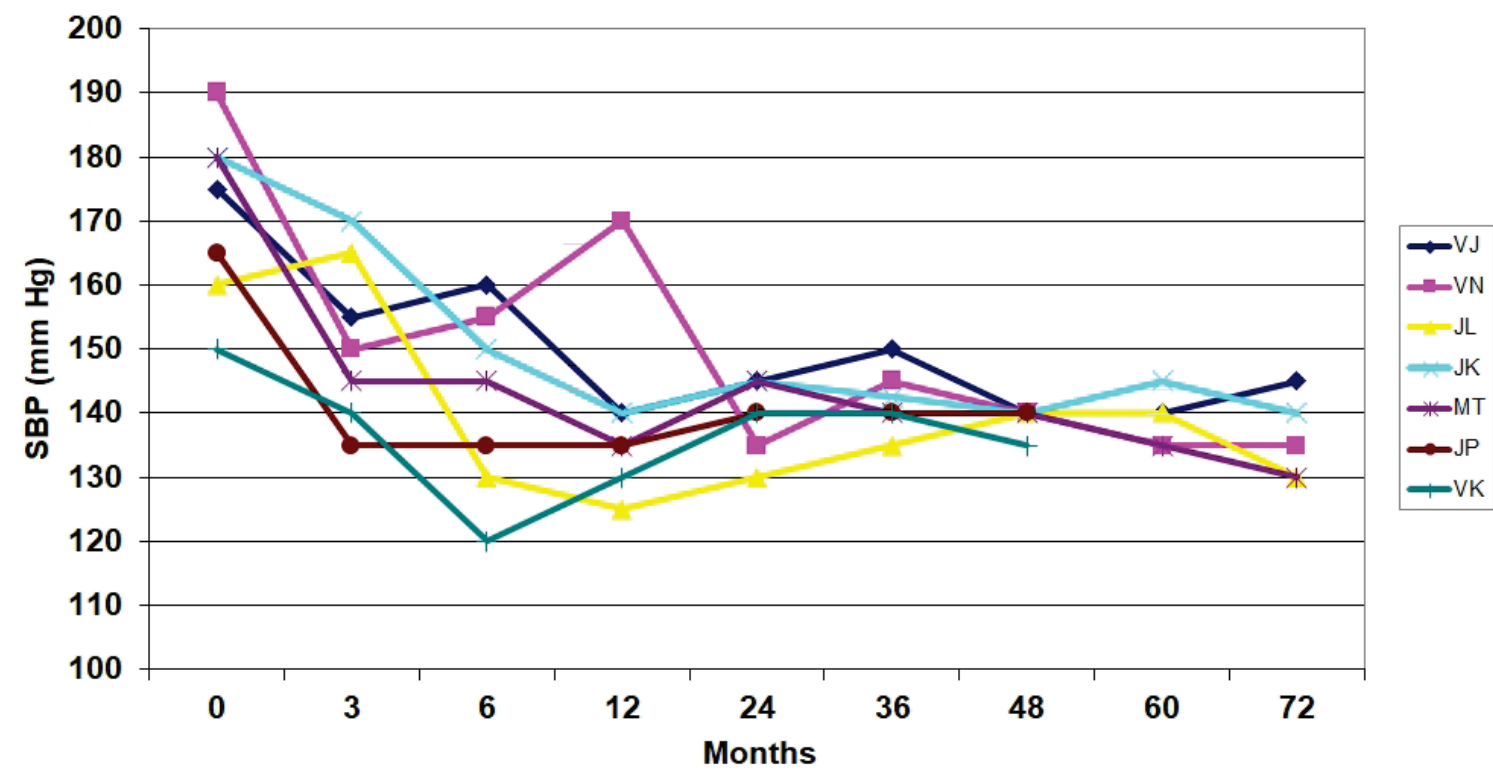

Fig. 1. Systolic blood pressure changes.

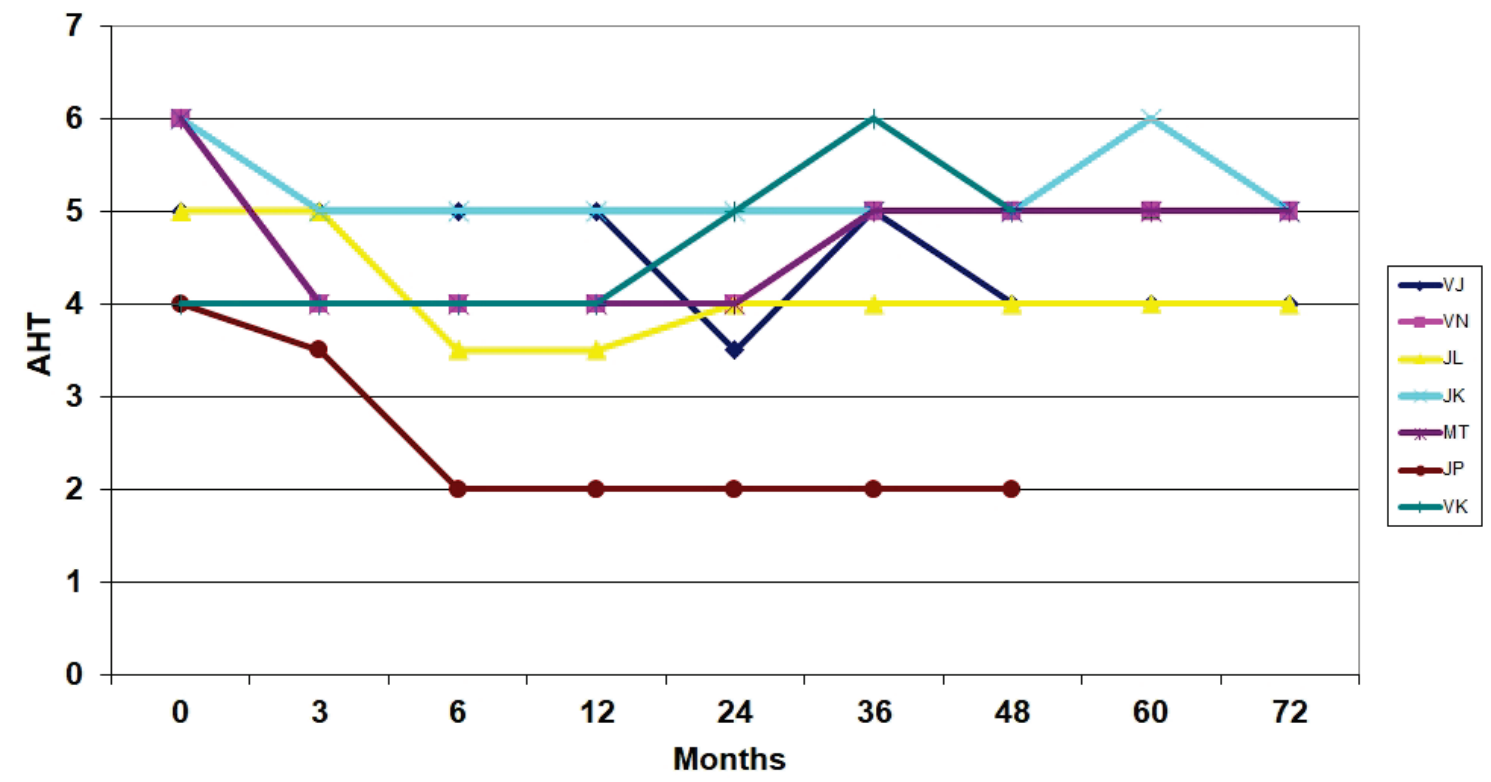

Fig. 2. Number of antihypertensive drug (AHT) changes.

Admittedly, our limited study including a mere seven patients is not as representative as the above multicenter studies. Still, we present data of seven treatment-resistant patients while on maximum medication who all experienced a BP reduction lasting 5 years and longer after RSD (with unchanged or even reduced medication). Over the past two years, we have performed another two RSD procedures using the multielectrode catheter with both patients showing improved control of hypertension previously resistant to medical therapy.

Given the above, we are confident that RSD still has a role to play in patients with failed antihypertensive medical therapy.

\section{Conflict of Interest}

There is no conflict of interest. 


\section{References}

AZIZI M, SAPOVAL M, GOSSE P, MONGE M, BOBRIE G, DELSART P, MIDULLA M, MOUNIER-VÉHIER C, COURAND PY, LANTELME P, DENOLLE T, DOURMAP-COLLAS C, TRILLAUD H, PEREIRA H, PLOUIN PF, CHATELLIER G: Renal Denervation for Hypertension (DENERHTN) investigators. Optimum and stepped care standardised antihypertensive treatment with or without renal denervation for resistant hypertension (DENERHTN): a multicentre, open-label, randomised controlled trial. Lancet 385: 1957-1965, 2015.

BHATT DL, KANDZARI DE, O'NEILL WW, D'AGOSTINO R, FLACK JM, KATZEN BT, LEON MB, LIU M, MAURI L, NEGOITA M, COHEN SA, OPARIL S, ROCHA-SINGH K, TOWNSEND RR, BAKRIS G: A controlled trial of renal denervation for resistant hypertension. N Engl J Med 370: 1393-1401, 2014.

CONSIGNY PM, DAVALIAN D, DONN R, HU J, RIESER M, STOLARIK D: Chemical renal denervation in rat. Cardiovasc Intervent Radiol 37: 218-223, 2014.

ESLER MD, KRUM H, SOBOTKA PA, SCHLAICH MP, SCHMIEDER RE, BÖHM M: Renal sympathetic denervation in patients with treatment-resistant hypertension (the SYMPLICITY HTN-2 Trial): a randomised controlled trial. Lancet 376: 1903-1909, 2010.

FADL ELMULA FE, JIN Y, YANG WY, THIJS L, LU YC, LARSTOP AC, PERSU A, SAPOVAL M, ROSA J, WIDIMSKÝ P, JACOBS L, RENKIN J, PETRÁK O, CHATTELIER G, SHIMADA K, WIDIMSKÝ J, KARIO K, AZIZI M, KJELDSEN SE, STAESSEN JA: European Network Coordinating Research On Renal Denervation (ENCOReD) Consortium. Meta-analysis of randomized controlled trials of renal denervation in treatment-resistant hypertension. Blood Press 24: 263-274, 2015.

KANDZARI DE, KARIO K, MAHFOUD F, COHEN SA, PILCHER G, POCOCK S, TOWNSEND R, WEBER MA, BÖHM M: The SPYRAL HTN Global Clinical Trial Program: Rationale and design for studies of renal denervation in the absence (SPYRAL HTN OFF-MED) and presence (SPYRAL HTN ON-MED) of antihypertensive medications. Am Heart $J$ 171: 82-91, 2016.

KANDZARI DE, BÖHM M, MAHFOUD F, TOWSEND RR, WEBER MA, POCOCK S, TSIOUFIS K, TOUSOULIS D, CHOI JW, EAST C, BRAR S, COHEN SA, FAHY M, PILCHER G, KARIO K: SPYRAL HTN-ON MED Trial Investigators. Effect of renal denervation on blood pressure in the presence of antihypertensive drugs: 6-month efficacy and safety results from the SPYRAL HTN-ON MED proof-of-concept randomised trial. Lancet 391: 2346-2355, 2018.

KRUM H, SCHLAICH M, WHITBOURN R, SOBOTKA PA, SADOWSKI J, BARTUS K, KAPELAK B, WALTON A, SIEVERT H, THAMBAR S, ABRAHAM WT, ESLER M: Catheter-based renal sympathetic denervation for resistant hypertension: a multicentre safety and proof-of-principle cohort study. Lancet 373: 1275-1281, 2009.

RICKE J, SEIDENSTICKER M, BECKER S, SCHIEFER J, ADANCHIC I, LOHFINK K, KANDULSKI M, HELLER A, MERTENS PR: Renal sympathetic denervation by CT-guided ethanol injection: A phase II pilot trial of a novel technique. Cardiovasc Intervent Radiol 39: 251-260, 2016.

ŠOCHMAN J, BÜRGELOVÁ M, PEREGRIN J: Renal denervation in the most serious form of resistant arterial hypertension. Physiol Res 65: 909-916, 2016.

TÁBORSKÝ M, RICHTER D, KUBÍKOVÁ T, HERMAN A, PEREGRIN J, HUSKOVÁ Z, KOPKAN L: Early morphologic alterations in renal artery wall and renal nerves in response to catheter-based renal denervation procedure in sheep: difference between single-point and multiple-point ablation catheters. Physiol Res 66: 601-614, 2017.

TÁBORSKÝ M, RICHTER D, TONAR Z, KUBÍKOVÁ T, HERMAN A, PEREGRIN J, HUSKOVÁ Z, KOPKAN L: Evaluation of later morphologic alterations in renal artery wall and renal nerves in response to catheter-based renal denervation in sheep: comparison of the single-point and multiple-point ablation catheters. Physiol Res 67: 891-901, 2018. 
TOWNSEND RR, MAHFOUD F, KANDZARI DE, KARIO K, POCOCK S, WEBER MA, EWEN S, TSIOUFIS K, TOUSOULIS D, SHARP ASP, WATKINSON AF, SCHMIEDER RE, SCHMID A, CHOI JW, EAST C, WALTON A, HOPPER I, COHEN DL, WILENSKY R, LEE DP, MA A, DEVIREDDY CM, LEA JP, LURZ PC, FENGLER K, DAVIES J, CHAPMAN N, COHEN SA, DEBRUIN V, FAHY M, JONES DE, ROTHMAN M, BÖHM M; SPYRAL HTN-OFF MED trial investigators*: Catheter-based renal denervation in patients with uncontrolled hypertension in the absence of antihypertensive medications (SPYRAL HTN-OFF MED): a randomised, sham-controlled, proof-of-concept trial. Lancet 390: 2160-2170, 2017. 